11. Krychevskyi, V. Yu. (1987). Professyohramma dyrektora shkoly. Problemy povyshenyia kvalyfykatsyy rukovodytelei shkol [Professional profile of the school principal. Problems of improving the qualifications of school principals]. Moscov, p.120. [in Russian].

12.Kontseptsiia pedahohichnoi kompetentnosti maibutnikh uchyteliv u systemi stupenevoi pidhotovky spetsialistiv pochatkovoi lanky osvity [The concept of pedagogical competence of future teachers in the system of step-by-step training of specialists of the initial level of education]. Available at: www.kgpa.km.ua (Accessed 6 Apr. 2019). [in Ukrainian].

13. Kudriavtsev, T.V. (1985). Uchebnoe posobye po kursu "Psykholohyia" [A manual for the course "Psychology"]. Psychology of vocational education and upbringing. Moscow, 108 p. [in Ukrainian].

14.Kuzmyna, N. V. (2001). Akmeolohycheskaia teoryia povyshenyia kachestva podhotovky spetsyalystov obrazovanyia [Akmeological theory of improving the quality of training of education specialists]. Moscow, p.144. [in Russian].

15. Maksymenko, S.D. Struktura ta osobystisni determinanty profesiinoi samorealizatsii subiekta [Structure and personal determinants of professional selfrealization of the subject]. Available at: www.kgpa.km.ua (Accessed 6 Apr. 2019 ). [in Ukrainian].

Стаття надійшла до редакції 16.04.2019

УДК 373.3/.5.091.21“199”:37.014.5

DOI:

Алла Загородня, кандидат педагогічних наук, доцент, провідний науковий співробітник відділу історії та філософії освіти Інституту педагогіки НАПН Украӥни

\title{
СПЕЦІАЛІЗОВАНІ ШКОЛИ ЯК ПРОВІСНИКИ ПРОФІЛЬНОГО НАВЧАННЯ У 90-Х РОКАХ ХХ СТОЛІТТЯ
}

У статті висвітлюються питання профільного навчання у 90-х роках ХХ століття. Наведено перелік нормативно-правових документів в яких висвітлено стратегічні завдання реформування системи освіти та сфери загальної середньої освіти. Розкрито сутність поняття “профільне навчання” згідно до визначення Національної доктрини розвитку освіти в Україні на 2012 - 2021 рр. Визначено мету та завдання профільного навчання. Окреслено принципи на яких трунтується профільне навчання. Охарактеризовано основні етапи становлення та розвитку профілізації загальної середньої освіти в Україні у 90-роках ХХ століття.

Ключові слова: диференціація; профільне навчання; профілізація; спеціалізовані школи; середня освіта; 90-ті роки ХХ століття.

Jim.15.

Alla Zahorodnya, Ph.D. (Pedagogy), Associate Professor, Leading Researcher of the History and Philosophy of Education Department Institute of Pedagogics of National Academy of Sciences of Ukraine

\section{SPECIALIZED SCHOOLS AS A HARBINGERS OF PROFILE EDUCATION IN THE 90'S OFTHE XX CENTURY}

The article covers the issues of profile education in the 90 's of the XX century. The essence of the concept "specialized education" according to the definition of the National doctrine of education development in Ukraine for 2012 - 2021 years is disclosed. The purpose and main tasks of profile education are defined. The principles on which the profile education is based (furctions, variations and alternatives, continuity, flexibility, diagnostic and predictive realization) are outlined. The main stages of the formation and development of profiling of general secondary education in Ukraine in the 90 years of the XX century are characterized. The regularities of the functioning of the internal and external forms of differentiation of training are defined. The difference between profile and in-depth study is found out. Conceptual foundations of the "Concept of differentiation of education in secondary schools" (1990), the Law of Ukraine "About education" (1991), "Programs of development of national education for 1991-1995", "Concepts of the secondary school of Ukraine" (1991), "Provisional Regulations of Secondary School of Ukraine" (1992), "State National Program Education" ("Ukraine XXI Century") (1993), "Regulations on General Education Institution" (1993), "Concepts of the State Standard of General Secondary Education" (1996), "Concepts of Establishment of the Network of Secondary Education Institutions" (1996), The Resolution "On Approval of the Basic Curriculum for General Education Institutions" (1998) are disclosed. The stages of the organization of institutions focused 


\section{СПЕЦАЛЗОВАНІ ШКОЛИ ЯК ПРОВІСНИКИПРОФІЛЬНОГО НАВЧАННЯ У 90-Х РОКАХ ХХ СТОЛІТТЯ}

on profile education are described. The task of creating a variant network of secondary education institutions is highlighted.

Keywords: differentiation; profile education; profiling; specialized schools; secondary education; 90s of XX century.

П остановка проблеми. Впровадження профільного навчання устарших класах середньої школи є одним із пріоритетних напрямів оновлення змісту сучасної освіти, серед ключових завдань якого: підвищення якості сучасної освіти, гуманізація навчання, задоволення освітніх потреб, самоактуалізація особистості, утвердження унікальності, неповторності і самоцінності індивідуальності школяра, що дозволяє за рахунок зміни у структурі, змісті й організації освітнього процесу враховувати інтереси та здібності учнів, створювати умови для їхньої освіти відповідно до професійних інтересів та життєвих планів.

Аналіз основних досліджень та публікацій. Різноманітні аспекти профілізації середньої освіти у старших класах середньої школи вивчали українські та зарубіжні науковці, а саме: висвітленням загальних теоретичних питань профілізації навчання опікувалися О. Бугайов, С. Броневщук, М. Бурда, Г. Бунтовська, М. Гузик, О. Корсакова, С. Логачевська, Х. Лійметс, Т. Логвіна-Бик, В. Монахов, Н. Огурцов, В. Орлов, А. Пінський, Л. Рожина, П. Сікорський, I. Унт, В. Фірсов, Н. Шиян, Н. Циркун, R. Aldrich, J.Bastian, A.Combe, L. Cremin, M. Curtis, D. Dean, P. Gordon, H.Gudjons, T. O’Brien, G. Walford та ін.; проблемі становлення та розвитку профільної школи присвячені праці Л. Березівської, Н. Бібік, Л. Бондар, Л. Ващенка, Н. Дічек, В. Кизенка, О. Коберника, В. Кузь, О. Локшиної, І. Лікарчук, В. Лугового, В. Майбороди, Ю. Мальованого, О. Корсакової,В. Огнев’юка,Л. Онищук,А. Самодрина, О. Сухомлинської, С. Трубачової, Н. Шиян та ін.; проблеми загальнопедагогічної тазагальнодидактичної специфіки профільного навчання знайшли відображення у дослідженнях С. Вольянської, Н. Дмітренко, Н. Ковчин, С. Кравцова, І. Лікарчука, А. Самодрина, М. Сметанського та ін.

Мета статті полягає у висвітленні закономірностей становлення та розвитку профілізації загальної середньої освіти у 90-роках $\mathrm{XX}$ століття.

Виклад основного матеріалу. Основними нормативно-правовими документами в яких висвітлено стратегічні завдання реформування системи освіти та сфери загальної середньої освіти є: Державна національна програма “Освіта. Україна XXI століття” (1993); Закони України: “Про освіту” (1991), "Про загальну середню освіту” (1999 р.); “Концепція загальної середньої освіти” (12-річна школа) (2001); “Концепція профільного навчання в старшій школі” (2003 р.), Галузева Програма впровадження профільного навчання на 2008 - 2010 роки (2008 р.) [3, 61].

Профільне навчання - це вид диференційованого навчання, який передбачає врахування освітніх потреб, нахилів та здібностей учнів і створення умов для навчання старшокласників відповідно до їхнього професійного самовизначення, що забезпечується за рахунок змін у цілях, змісті та структурі організації навчання [3, 60].

У “Національній доктрині розвитку освіти в Україні на 2012 - 2021 рр." профілізація трактується як один із шляхів забезпечення рівного доступу дітей до освіти [12].

Мета профільного навчання полягає у забезпеченні рівних можливостей для доступу учнівської молоді до здобуття загальноосвітньої профільної та початкової допрофесійної підготовки; гарантування неперервної освіти впродовж усього життя; виховання особистості, здатної до самореалізації, професійного зростання й мобільності в умовах реформування сучасного суспільства [9].

Основними завданнями диференціації змісту освіти є: створення умов для врахування й розвитку навчально-пізнавальних і професійних інтересів, нахилів,здібностей і потреб учнів старшої школи в процесі їхньої загальноосвітньої підготовки; виховання в учнів любові до праці, забезпечення умов для їхнього життєвого і професійного самовизначення, формування готовності до свідомого вибору й оволодіння майбутньою професією; формування соціальної, комунікативної, інформаційної, технічної, технологічної компетенцій учнів на допрофільному рівні, спрямування підлітків щодо майбутньої професійної діяльності; забезпечення наступноперспективних зв'язків між загальною середньою і професійною освітою відповідно до обраного профілю [9].

Профільне навчання грунтується на таких принципах: фуркації (розподіл учнів за рівнем освітньої підготовки, інтересами, потребами, здібностями і нахилами); варіативності й альтернативності (освітніх програм, технологій навчання і навчально-методичного забезпечення); наступності та неперервності (між допрофільною підготовкою і профільним навчанням, професійною підготовкою); гнучкості (змісту і форм організації профільного навчання, у тому числі дистанційного; забезпечення можливості зміни профілю); 


\section{СПЕЦАЛЗОВАНІ ШКОЛИ ЯК ПРОВІСНИКИПРОФІЛЬНОГО НАВЧАННЯ}

У 90-Х РОКАХ ХХ СТОЛІТТЯ

діагностико-прогностичної реалізованості (виявлення здібностей учнів для їх обгрунтованої орієнтації на профіль навчання) [7, 238].

Становлення та розвиток профілізації загальної середньої освіти у 90-роках ХХ століття, відбувалося у декілька етапів. І-й етап - 1990 кінець 90-их років XX ст. - розвиток навчальних закладів нового типу, становлення профільного навчання в загальноосвітній школі. Упродовж цього періоду суб'єктами управлінської ініціативи СРСР під тиском громадськості було здійснено низку заходів: змінено напрям освітньої ідеології на розвиток варіантної освіти та профільного навчання, виділено проблему профільного навчання на загальносоюзному рівні. II-й етап 1999 р. - законодавче введення профільного навчання в старшій школі незалежної України та пов'язаний із формуванням нормативно-правової бази, створенням шкіл нового типу та запровадженням уних профільної диференціації. III-й етап - 1996 р. - формування змісту освіти загальноосвітньої школи, формування державного стандарту загальної середньої освіти, визначення інваріантної та варіативної складової змісту навчання [7, 243].

11 квітня 1990 року на засіданні Президії АПН СРСР було заслухано “Концепцію диференціації навчання у середній загальноосвітній школі”, розроблену колективом співробітників НДІ загальної середньої освіти АПН СРСР. Згідно до Концепції, метою диференційованого навчання із психолого-педагогічної точки зору $\epsilon$ індивідуалізація навчання, основана на створенні оптимальних умов для виявлення задатків, розвитку інтересів та здібностей кожного школяра; із соціальної точки зору - цілеспрямований вплив на формування творчого, інтелектуального, професійного потенціалу суспільства з метою раціонального використання можливостей кожного члена суспільства і його взаємовідносин із соціумом; $з$ дидактичної точки зору - вирішення назрілих проблем школи шляхом створення нової методичної системи диференційованого навчання учнів, що грунтується на принципово новій мотиваційній основі $[8,42]$.

В основу концепції було покладено дві форми диференціації: внутрішню і зовнішню. Внутрішня диференціація передбачала різне навчання у великих групах учнів (класах), відповідно до певних ознак, варіативність темпу вивчення матеріалу, диференціацію навчальних завдань, вибір різних видів діяльності, визначення характеру і ступеня дозування допомоги вчителя. Внутрішня диференціація передбачала використання як традиційної форми врахування індивідуальних особливостей учнів (диференційований підхід), так і рівневої диференціації на основі планування результатів навчання.

Зовнішня диференціація розглядалася як створення на основі певних принципів (інтересів, здібностей, нахилів, досягнутих результатів, проектованої професії) відносно стабільних груп, у яких зміст освіти та поставлені вимоги відрізняються. Зовнішня диференціація, відповідно до концепції, могла здійснюватися або в рамках селективної системи (вибір профільного класу чи класу із поглибленим вивченням циклу предметів), чи в рамках елективної системи (вільного вибору навчальних предметів для вивчення на базі інваріантного ядра освіти) [8, 43].

У Концепції вперше було з'ясовано різницю між профільним і поглибленим навчанням, яка полягає в ступені спеціалізації i, як наслідок, у глибині відповідних курсів і широті охоплення контингенту школярів. Поглиблене навчання відзначається просунутим рівнем підготовки школярів, який дозволяє досягти високих результатів і разом 3 тим обмежує кількість учнів. Профільне навчання вирізняється демократичною і широкою формою фуркації школи. У кожному із профілів увага приділялася профілюючим предметам, на які виділялася істотна частка загального навчального навантаження. Для профілюючих предметів компенсувалися втрати навчального часу за рахунок загального скорочення навчального навантаження [8, 43]. В умовах малокомплектних шкіл доцільно було реалізовувати диференційоване навчання через факультативи.

У Концепції зазначалося, що розроблений базовий план передбачає 2-річну профільну диференціацію. Проте рекомендувалося створення трирічної старшої школи $з$ тим, щоб забезпечити повноцінну загальноосвітню підготовкуз поглибленим вивченням тих чи інших циклів предметів. Опорною базою для закладів нового типу мали стати заклади вищої освіти, технікуми, підприємства і УПК, виробничі і науково-виробничі кооперативи, а також державні й суспільні організації $[8,47]$.

У зв'язку з прийняттям 24 серпня 1991 року “Акту проголошення незалежності України”, що засвідчив створення самостійної Української держави, 23 травня 1991 року Верховною Радою України було прийнято Закон України "Про освіту”. Відповідно до закону, повна загальна середня освіта має бути обов'язковою й забезпечувати всебічний розвиток дитини як особистості, їі нахилів, здібностей, талантів, професійне самовизначення, формування 
загальнолюдської моралі, засвоєння визначеного суспільними, національно-культурними потребами обсягу знань про природу, людину і суспільство, екологічне виховання, фізичне вдосконалення. Здобуття загальної середньої освіти у навчальновиховних закладах в обсязі освітнього мінімуму оплачується державою $[13,11]$.

Основним середнім навчально-виховним закладом, що здійснює загальноосвітню підготовку, відповідно до Ст. 29, є середня загальноосвітня школа трьох ступенів, а саме: початкова школа, основна школа, старша школа, де кожна із шкіл може діяти та функціонувати автономно. Для розвитку здібностей, талантів дітей створюються профільні класи, спеціалізовані школи, гімназії, ліцеї, а також різні типи навчальновиховних комплексів, об'єднань $[13,11]$.

Для реалізації основ Закону “Про освіту” 1991 року колегією Міністерства народної освіти УРСР було розроблено "Програму розвитку народної освіти на 1991 - 1995 рр.” У Програмі передбачалися зміни у шкільній мережі, зокрема, розширення мережі ліцеїв, гімназій, шкіл із поглибленим вивченням окремих предметів, спеціалізованих шкіл, а також відкриття приватних, кооперативних шкіл, альтернативних державним. Відповідно до програми планувалося удосконалення змісту загальноосвітньої підготовки, оновлення навчально-методичних комплексів, забезпечення диференціації і різнорівневого підходу при викладанні шкільних дисциплін. Передбачалося скорочення обов'язкового навантаження учнів, розширення шкільного компонента освіти, введення додаткових спецкурсів, факультативів, курсів за вибором учнів, більш широке запровадження профільного навчання $[14,7]$.

В рамках реалізації “Програми розвитку народної освіти” у вересні 1991 року було прийнято “Концепцію середньої загальноосвітньої школи України", де зазначалося, що єдина за своєю сутністю, метою і завданнями, основним змістом навчання і виховання загальноосвітня школа функціонує у вигляді навчальних закладів різних типів, а саме: середня загальноосвітня школа, що забезпечує базовий рівень освіти 3 усіх загальноосвітніх предметів; школа $з$ поглибленим вивченням окремих предметів, що забезпечує базовий рівень освіти з більшості навчальних предметів, а 3 деяких - вищий рівень знань, найчастіше на II та III ступенях навчання; школа 3 профільним навчанням, або спеціалізована школа, що передбачає базовий рівень освіти 3 більшості навчальних предметів і поглиблені знання з одного або декількох профілів: наукового спрямування (фізико-математичного, фізикотехнічного, хіміко-біологічного, сільськогосподарського, філологічного, історико-суспільствознавчого, економічного, педагогічного тощо); художнього спрямування (музичного, образотворчого, акторського, вокального, хореографічного тощо); спортивного (за різними видами спорту) на II і III ступенях. Кожному профілю відповідало поглиблене вивчення певної групи предметів, а також вивчення спецкурсів $[5,1]$.

У серпні 1992 року Міністерством освіти України було затверджено “Тимчасові положення про середню загальноосвітню школу України”, про гімназію, про ліцей, приватну школу, відповідно до якого поряд із обов'язковими передбачалося вивчення предметів за вибором. За наявності необхідних умов та з урахуванням запитів учнів запроваджувався один або декілька профілів навчання (гуманітарний, фізико-математичний, хіміко-біологічний, технічний, сільськогосподарський, економічний та ін.). Учні, які до закінчення школи II ступеня не визначилися із профілем навчання, мали залишатися у звичайних класах. У школі всіх ступенів варіантність загальної середньої освіти забезпечувалася наявністю в її змісті державного та шкільного компонентів. Державний стандарт загальної середньої освіти визначався Міністерством освіти України, а шкільний школою з урахуванням інтересів та бажань учнів, їніх батьків, а також культурно-етнічних особливостей регіону [15, 3 - 17]. Відповідно до Положення про гімназії та Положення про ліцеї, ці середні заклади повинні були функціонувати для обдарованих і здібних дітей. Гімназії - у складі 5 11 класів, ліцеї - 10 - 11 або 8 - 11 класів $[10,18]$.

3 листопада 1993 року постановою Кабінету Міністрів України “Державна національна програма “Освіта” (“Україна XXI століття”)", головна мета якої полягала у визначенні стратегії розвитку освіти в Україні на найближчі роки та перспективу XXI століття. Відповідно до Програми, одним із стратегічних завдань реформування освіти в Українській державі було реформування іï змісту, а саме вироблення державних стандартів і відповідне формування системи й обсягу знань, умінь, навичок творчої діяльності, інших якостей особистості на різних освітніх та кваліфікаційних рівнях, а також відбір і структурування навчально-виховного матеріалу на засадах диференціації та інтеграції, забезпечення альтернативних можливостей для одержання освіти відповідно до індивідуальних потреб та здібностей [2].

У документі вагоме місце відводилося школам нового типу (гімназіям, ліцеям, спеціальним 


\section{СПЕЦАЛЗОВАНІ ШКОЛИ ЯК ПРОВІСНИКИПРОФІЛЬНОГО НАВЧАННЯ}

У 90-Х РОКАХ ХХ СТОЛІТТЯ

закладам для обдарованих дітей, школам (класам) 3 поглибленим вивченням окремих предметів, навчально-виховним комплексам, недільним, приватним школам тощо), загальноосвітнім школам-інтернатам, що зорієнтовані на спеціалізовану поглиблену підготовку з технічного, спортивного, художньоестетичного та інших напрямів, на відкриття при цих школах окремих класів для обдарованих дітей [2].

19 серпня 1993 року Постановою Кабінету Міністрів України було затверджено "Положення про загальноосвітній навчальний заклад”. Відповідно до Положення, основним видом навчально-виховних закладів, що здійснюють загальноосвітню підготовку на рівні державних стандартів, є середня загальноосвітня школа трьох ступенів. Для розвитку природної обдарованості дітей створюються спеціалізовані школи і профільні класи, гімназії та ліцеї: спеціалізована школа і профільні класи забезпечують поглиблене вивчення одного або кількох базових навчальних предметів. Вони можуть діяти у складі шкіл першого-третього та другого-третього ступенів. Гімназія - середній загальноосвітній навчально-виховний заклад другого-третього ступеня, що забезпечує науковотеоретичну гуманітарну, загальнокультурну підготовку обдарованих і здібних дітей. Ліцей середній загальноосвітній навчально-виховний заклад, що забезпечує здобуття учнями освіти понад державний освітній мінімум і здійснює науково-практичну підготовку талановитої учнівської молоді. Термін навчання в ньому може бути таким, як у школі третього ступеня, або на 1 -2 роки більше $[11,8]$.

1996 року Міністерством освіти України було затверджено "Концепцію державного стандарту загальної середньої освіти” та проект "Базового навчального плану загальноосвітньої школи". Відповідно до Концепції, державний стандарт загальної середньої освіти - це унормована система показників про освіченість особи, що реалізується комплексом нормативних документів, які визначають суспільно зумовлений зміст загальної середньої освіти та вимоги й гарантії держави щодо її одержання громадянами $[4,4]$. А от базовий навчальний план визначав зміст загальної середньої освіти в його цілісному уявленні як системи знань, які повинні опановувати учні на певному етапі навчання у школі. Він об'єднував державний компонент, як інваріантну частину, та регіональний і шкільний компоненти, як варіативну його частину $[4,4]$.

5 серпня 1998 року було прийнято Постанову
"Про затвердження Базового навчального плану загальноосвітніх навчальних закладів”, згідно 3 якою 31 вересня 2001 року повинен був введений в дію “Базовий навчальний план», який задавав загальну структуру змісту середньої освіти через інваріативну та варіативну складові. Інваріантна складова змісту мала стати спільною для всіх середніх закладів освіти України і визначала іiі загальнодержавний компонент, вона становила $76,4 \%$ - 84,3\% усього навчального часу. Варіативна складова змісту повинна була формуватися закладом освіти з урахуванням інтересів, здібностей, життєвих планів учнів, а також мала відображати в змісті освіти етнічні, історичні, економічні, природничі, соціокультурні особливості регіону, що не увійшли до інваріантної частини, але були суттєвим елементом формування світогляду, патріотичних почуттів, необхідних для повноцінного входження молодої особистості в життя в умовах конкретного регіону. Варіативна складова становила 21,3 - 29,2 \% усього навчального часу $[1,5]$.

Документом, який сприяв розвитку шкіл нового типу та профільного навчання, була "Концепція становлення мережі середніх закладів освіти” для розвитку творчої обдарованості, затверджена 26 червня 1996 року, у якій зазначалося, що завдання створення варіантної мережі середніх закладів освіти для розвитку творчої обдарованості, яка б відповідала загальнолюдським цінностям та інтересам особистості, суспільства, держави, передбачає побудову диференційованої системи освіти та організацію навчання і виховання обдарованої учнівської молоді не тільки у гімназіях, колегіумах, ліцеях, спеціалізованих школах, але й у загальноосвітніх школах трьох ступенів, позашкільних закладах, наукових об'єднаннях та культурно-освітніх установ за місцем проживання $[6,57]$.

Згідно документу, гімназії, ліцеї, колегіуми, спеціалізовані школи могли створюватися за виконання таких умов: визначення концептуальних засад їх діяльності; наявності приміщення, яке відповідає санітарно-гігієнічним вимогам для дітей відповідного віку; затвердження навчальних планів, програм, підручників, навчальних посібників; конкурсного добору педагогічних працівників; створення системи пошуку, відбору, організації навчання та виховання здібної й обдарованої учнівської молоді [6, 58].

У Концепції чітко описувалися етапи організації окреслених закладів, а саме: підготовчий (розробка концепції, статуту, навчальних планів, програм, критеріїв пошуку і добру здібної та 


\section{СПЕЦАЛІЗОВАНІ ШКОЛИ ЯК ПРОВІСНИКИПРОФІЛЬНОГО НАВЧАННЯ У 90-Х РОКАХ ХХ СТОЛІТТЯ}

обдарованої учнівської молоді й педагогічних кадрів, реєстрація статуту, визначення юридичної адреси, джерел фінансування та матеріальнотехнічного оснащення); організаційний (прийняття рішення засновником про створення закладу освіти, визначення мети і завдань його діяльності, дидактичне та інформаційне забезпечення); апробаційний (організація навчально-виховного процесу, практична перевірка та впровадження змісту освіти, формування колективу, аналіз роботи, корегування та окреслення перспектив діяльності); технологічний (функціонування на основі результатів апробаціï) $[6,59]$.

Висновки. Проведений історико-педагогічний аналіз дозволив зробити висновок про те, що профілізація загальної середньої освіти у 90-роках $\mathrm{XX}$ століття була актуальною в усі періоди розвитку вітчизняної педагогіки, але на різних етапах функціонування школи реалізовувалася порізному. Якщо на ранніх етапах розвитку педагогіки і школи профілізація базувалася на зовнішніх відмінностях - статевих, вікових, станових, класових, то надалі вона була зорієнтована на відхід від утилітарної системи освіти, орієнтацію освітньої політики на інтереси, здібності та запити учнів через розширення можливостей освіти за вибором, координацію іiї 3 перспективними потребами ринку праці.

\section{ЛІТЕРАТУРА}

1. Базовий навчальний план середніх закладів освіти України. Інформаційний збірник Міністерства освіти України. 1998. № 5. С. 4- 10.

2. Державна національна програма "Освіта" (Україна XXI століття). Історія української школи і педагогіки : хрестоматія / уклад. О. О. Любар ; за ред. В. Г. Кременя. Київ, 2005. С. 600-623.

3. Загородня А. А. Диференціація змісту навчання у старшій школі як ефективна умова реалізації особистісно-орієнтованої парадигми освіти. Педагогічна освіта: теорія і практика: зб. наукових праць. Серія: Педагогіка. 2018. Вип. № 25 (2-2018). С. 59-65.

4. Концепція державного стандарту загальної середньої освіти України. Освіта України. 1997. 15 серпня. С. 4-5.

5. Концепція середньої загальноосвітньої національної школи України. Рад. освіта. 1991. 14 серп. (№ 65). С. 1-3.

6. Концепція становлення мережі середніх закладів освіти для розвитку творчої обдарованості. Інформаційний збірник Міністерства освіти. 1996. № 17-18. С. 53-64.

7. Кушнір В. М. Профільне навчання в історії розвитку вітчизняної школи (друга половина XIX -
XX ст.) : монографія. Умань, 2016. 409 с.

8. Монахов В. М., Орлов, В. А., Фирсов В. В. Дифференциация обучения в средней школе. Советская педагогика. 1990. № 8. С. 42-47.

9. НМЦ Профільного навчання Науковометодичного центру профільного навчання Інституту післядипломної педагогічної освіти Київського університету імені Бориса Грінченка URL: https://sites.google.com/site/smcprofil/ materials/for_organizers/material_1.

10. Положення про гімназії. Інформаційний збірник Міністерства народної освіти Української РСР. 1992. № 15-16. С. 17-22.

11. Положення про середній загальноосвітній навчально-виховний заклад. Освіта. 1993. 3 вересня (№ 29). С. 8-9.

12. Про Національну доктрину розвитку освіти: Указ Президента України від 25.06.2013 344/2013. URL: http://zakon2.rada.gov.ua/laws/show/344/2013

13. Про освіту : закон Української Радянської Соціалістичної Республіки від 23.05.1991 № 1060ХІІ. Рад. школа. 1991. № 9. С. 5-19.

14. Програма розвитку народної освіти Української РСР наперехідний період(1991-1995 pp.). Інформаційний збірник Міністерства народної освіти Української РСР. 1991. № 15-16. С. 4-36.

15. Тимчасове положення про середню загальноосвітню школу України. Інформаційний збірник Міністерства народної освіти України. 1992. № 15-16. С. 3-17.

\section{REFERENCES}

1. Bazovyi navchalnyi plan serednikh zakladiv osvity Ukrainy (1998). [The basic curriculum of secondary education institutions Ukraine]. Information collection of the Ministry of Education of Ukraine. No. 5, pp.4-10. [in Ukrainian].

2. Liubar, O. O. (2005). Derzhavna nacionalna programa "Osvita" (Ukraina XXI stolittia) [State national program "Education" (Ukraine XXI century)]. History of the Ukrainian school and pedagogy: reader. Kyiv, pp.600-623. [in Ukrainian].

3. Zahorodnia, A. A. (2018). Dyferentsiatsiia zmistu navchannia u starshii shkoli yak efektyvna umova realizatsii osobystisno-oriientovanoi paradyhmy osvity [Differentiation of the content of education in senior school as an effective condition of realization personalized-oriented paradigm of education]. Teacher education: Theory and Practice: Coll. of scientific papers. Series: Pedagogy. Vol. 25 (2-2018), pp.59-65. [in Ukrainian].

4. Kontseptsiia derzhavnoho standartu zahalnoi serednoi osvity Ukrainy (1997). [Concept of the state standard of general secondary education of Ukraine]. Education of Ukraine, pp.4-5. [in Ukrainian]. 
5. Kontseptsiia serednoi zahalnoosvitnoi natsionalnoi shkoly Ukrainy (1991). [The concept of national secondary school Ukraine]. Sov. education. Vol 65, pp.1-3. [in Ukrainian].

6. Kontseptsiia stanovlennia merezhi serednikh zakladiv osvity dlia rozvytku tvorchoi obdarovanosti (1996). [The concept of formation of a network of secondary education institutions for the development of creative talent]. Information collection of the Ministry of Education.Vol. 17-18, 53-64 [in Ukrainian].

7. Kushnir, V. M. (2016). Profilne navchannia v istorii rozvytku vitchyznianoi shkoly (druha polovyna XIX - XX st.) : monohrafiia [Profile training in the history of the development of the national school (second half of XIX - XX centuries.): monograph]. Uman, p.409. [in Ukrainian].

8. Monakhov, V. M. (1990). Dyfferentsyatsyia obuchenyia $\mathrm{v}$ srednei shkole [Differentiation of education in high school]. Soviet pedagogy. Vol. 8, pp.42-47. [in Ukrainian].

9. NMTs Profilnoho navchannia Naukovometodychnoho tsentru profilnoho navchannia Instytutu pisliadyplomnoi pedahohichnoi osvity Kyivskoho universytetu imeni Borysa Hrinchenka [NMC of Profile training training of the Scientificmethodical center of profile education of the Institute of postgraduate pedagogical education of the Borys Grinchenko Kyiv University]. [Electronic resource]. Available at: https://sites.google.com/site/smcprofil/ materials/for_organizers/material_1 [in Ukrainian].

10. Polozhennia pro himnazii. Informacijnyj zbirnyk
Ministerstva narodnoyi osvity Ukrayinskoyi RSR (1992). [Regulations of the gymnasium]. Vol. 15-16, pp.17-22. [in Ukrainian].

11. Polozhennia pro serednii zahalnoosvitnii navchalno-vykhovnyi zaklad (1993). [Regulations of general secondary educational institution]. Education. Vol. 29, pp.8-9. [in Ukrainian].

12. Pro Natsionalnu doktrynu rozvytku osvity : Ukaz Prezydenta Ukrainy vid 25.06.2013 344/2013 [About the National Doctrine of Education Development: Decree of the President of Ukraine from 25.06.2013, No 344/2013]. [Electronic resource]. Available at: http://zakon2.rada.gov.ua/ laws/show/344/2013 [in Ukrainian].

13. Pro osvitu : zakon Ukrainskoi Radianskoi Sotsialistychnoi Respubliky vid 23.05.1991 № 1060XII (1991). [About education: the law of the Ukrainian Soviet Socialist Republic from 23.05.1991, No 1060XII ]. Sov. school. Vol. 9, pp.5-19. [in Ukrainian].

14. Prohrama rozvytku narodnoi osvity Ukrainskoi RSR na perekhidnyi period (1991-1995 rr.) [Program of development of national education of the Ukrainian SSR for the transitional period (1991-1995)]. Information collection of the Ministry of National Education of the Ukrainian SSR. Vol. 15-16, pp.43. [in Ukrainian].

15. Tymchasove polozhennia pro seredniu zahalnoosvitniu shkolu Ukrainy (1992). [Provisional Provision on Secondary School of Ukraine]. Information collection of the Ministry of National Education of Ukraine. Vol. 15-16, pp.3-17. [in Ukrainian].

Стаття надійшла до редакції 15.03.2019

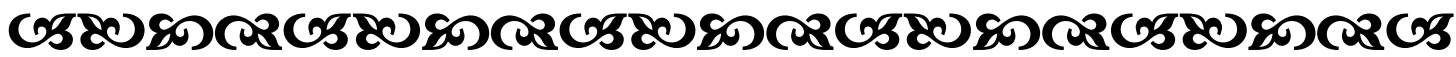

\author{
"Була бмета поставлена - а ланщюжок проб і помилок сам приведе до бажаного \\ результату". \\ Харукі Мурақамі \\ японський письменник і перекладач
}

"Кожна людина повинна переважно братися за те, що для неї можливо і що для неї пристойно".

Apicmomess

давньогрецький вчений-енциклопедист

“Самостійні думки витікають тільки із самостійно придбаних знань”.

Костянтин $\mathcal{Y ш и н с ь к и и ̆ ~}$ український педагог

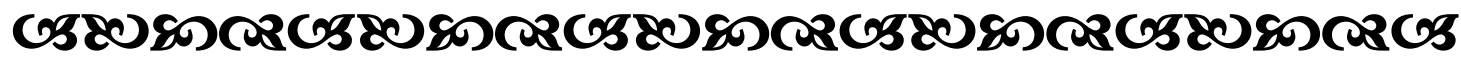

